\title{
SI on economic costs of invasions - Feeling the pinch: global economic costs of crayfish invasions and comparison with other aquatic crustaceans
}

\section{Antonin Kouba}

University of South Bohemia in České Budějovice, Faculty of Fisheries and Protection of Waters, South Bohemian Research Center of Aquaculture and Biodiversity of Hydrocenoses, Zátiší 728/II, 38925

Vodňany, Czech Republic

Francisco J. Oficialdegui

Doñana Biological Station (EBD-CSIC), Department of Wetland Ecology, Seville, Spain

\section{Ross N. Cuthbert}

GEOMAR Helmholtz-Zentrum für Ozeanforschung Kiel, Kiel, Germany

\section{Melina Kourantidou}

Marine Policy Center, Woods Hole Oceanographic Institution, Woods Hole, MA, USA

Josie South

South African Institute for Aquatic Biodiversity (SAIAB), Centre for Invasion Biology, Makhanda, South Africa

\section{Elena Tricarico}

University of Florence, Department of Biology, Sesto Fiorentino (FI), Italy

\section{Boris Leroy}

Muséum National d'Histoire Naturelle, Sorbonne Universités, Université de Caen Normandie, Université des Antilles, CNRS, IRD, Unité Biologie des Organismes et Ecosystèmes Aquatiques (BOREA UMR 7208), Paris, France

\section{Rudolphe Gozlan}

ISEM, Université Montpellier, CNRS, EPHE, IRD, Montpellier, France

\section{Franck Courchamp}

Université Paris-Saclay, CNRS, AgroParisTech, Ecologie Systématique Evolution, Orsay, France

\section{Phillip J Haubrock ( $\square$ Phillip.haubrock@senckenberg.de )}

Senckenberg Research Institute and Natural History Museum Frankfurt, Department of River Ecology and Conservation, Gelnhausen, Germany https://orcid.org/0000-0003-2154-4341

\section{Research Article}

Keywords: activity sector, Amphipoda, freshwater and marine ecosystems, Decapoda, InvaCost, invasive alien species, invertebrates, monetary impact 
Posted Date: April 3rd, 2021

DOl: https://doi.org/10.21203/rs.3.rs-381161/v1

License: (9) This work is licensed under a Creative Commons Attribution 4.0 International License. Read Full License

Version of Record: A version of this preprint was published at Science of The Total Environment on December 28th, 2021. See the published version at https://doi.org/10.1016/j.scitotenv.2021.152325. 


\section{Abstract}

Despite voluminous literature identifying invasive species impacts, understandings of monetary costs remain limited. Recently, profound impacts have been attributed to invasive crustaceans, but associated monetary costs lack synthesis. Here, we analyse globally reported costs of invasive freshwater crayfish across taxonomic, spatial and temporal descriptors. Moreover, we compare their cost magnitude to other invasive crustaceans - crabs, amphipods and lobsters. Between 2000 and 2020, crayfish caused US\$ 1.28 billion in reported costs; the vast majority (95\%) attributed to Astacidae (principally the signal crayfish Pacifastacus leniusculus) and the remainder to Cambaridae. According to reports, crayfish costs mostly impacted European economies (US\$ 1.23 billion), followed by costs reported for North America and Asia. Despite well-known damages caused by invasive crayfish, costs were unreported elsewhere, highlighting knowledge gaps and challenges in cost quantifications. Invasive crayfish costs increased exponentially in the last two decades, averaging at US\$ 61 million per-annum. Invasive crabs caused costs of similar magnitude (US\$ 1.25 billion; US $\$ 53$ million per-annum) but were mostly confined to North America (95\%). Damage-related costs dominated for both crayfish (83\%) and crabs (99\%), with management spending lacking. Reported economic impacts from amphipods (US\$178.8 thousand) and lobsters (US\$ 44.6 thousand) were considerably lower. We identify burgeoning economic costs from these invasive groups yet highlight pervasive knowledge gaps at multiple scales. Further cost reporting is required to better-ascertain the true scale of monetary costs caused by invasive aquatic crustaceans.

\section{Introduction}

Owing to their sensitivity to the effects of climate change (Woodward et al. 2010) and a range of other anthropogenic pressures (Strayer 2010; Darwell et al. 2018), freshwater ecosystems have been characterised as the most threatened ecosystems worldwide (Reid et al. 2019). Invasive alien species (IAS) are considered among the strongest drivers of biodiversity decline, as well as disruptors of ecosystem functioning and ecosystem services provisioning (Blackburn et al. 2019; Pyšek et al. 2020), with concerns rising as invasion rates continue to increase (Seebens et al. 2017; 2020; Bailey et al. 2020). Freshwater ecosystems are especially vulnerable to the introduction of alien species (Frederico et al. 2019). Despite the recognition of these ongoing losses and risks, the capacity of various countries to effectively combat and prevent biological invasions remains limited (Early et al. 2016; Faulkner et al. 2020). This can be in part attributed to limited understanding of the magnitude of losses and the expenditure required to avoid those or prevent them from happening in the future.

In recent years, there have been significant advances in understanding the ecological impacts of IAS on recipient aquatic ecosystems (e.g. Jackson 2015; Dick et al. 2017; Bradley et al. 2019; Haubrock et al. 2019b). Whilst frameworks for categorising invader socioeconomic impacts have advanced throughout the years in response to the challenges associated to monetizing socioeconomic impacts (Bacher et al. 2018), the paucity of quantified costs incurred by invasions is weakening the rationale for policy makers to invest the sparse available resources toward prevention, control and eradication. Pimentel et al. (2000; 2005), followed by Kettunen et al. (2009), summarized the costs of IAS on large spatial scales. Despite 
the methodological shortcomings of these studies (Charles and Dukes 2008; Cuthbert et al. 2020a), they partly succeeded in raising awareness of IAS-induced costs (Hoffmann and Broadhurst 2016). The existence of information on costs inferred from IAS is of utmost importance; a lack thereof may be misleading for policy making and resource management as well as minimize the awareness and preoccupation regarding IAS. Despite recent efforts to analyze invasion costs of specific taxonomic groups (Bradshaw et al. 2016; Haubrock et al. this issue), across various regions (Crystal-Ornelas et al. in review; Haubrock et al. in press; Liu et al. in review) or habitat types (Cuthbert et al. in review), a detailed collective understanding is still lacking for many taxa and regions. Filling this knowledge gap is critical for informing policy responses, efficiently allocating resources for management and avoiding future losses.

Crayfish are the largest of freshwater invertebrates and among the longest-lived (Souty-Grosset et al. 2006), with almost 700 currently known species (Crandall and De Grave 2017). Owing to their substantial individual size and ability to reach high densities, their omnivorous nature and dominance in trophic interactions and ecosystem engineering (Reynolds and Souty-Grosset 2011), they play important ecological roles (Twardochleb et al. 2013; Lipták et al. 2019; Veselý et al. 2020). Their introduction globally has been mostly for aquaculture, fishery and ornamental purposes (Ackefors 2000; Faulkes 2015; Weiperth et al. 2020), with resulting invasions generally leading to severe ecosystem and socioeconomic losses (Lodge et al. 2012; Madzivanzira et al. 2020). In some cases, the entire functioning of freshwater ecosystems has been irreversibly altered by alien crayfish (Lodge et al. 2000; Gherardi 2006). The increasing recognition of severe impacts caused by alien crayfish has attracted increasing research attention about their introduction pathways, risks, ecological interactions and impacts (Gherardi et al. 2011; Haubrock et al. 2019a; South et al. 2019; 2020). Introductions of North American crayfish species are particularly problematic, as they often also vector Aphanomyces astaci Schikora (Oomycetes), the causative agent of crayfish plague. This oomycete is included among the IUCN 100 world's worst IAS list (Lowe et al. 2000), given the highly susceptibility and mortality of crayfish species not originating from this continent (Svoboda et al. 2017).

Invasive crayfish species (ICS) are, however, not the only invasive crustaceans with proven impacts on recipient communities (Lodge et al. 2012; Twardochleb et al. 2013). Similar to them, numerous invasive crabs have been recognized as a large threat, with marked adverse ecological and socioeconomic effects. Examples include the Chinese mitten crab Eriocheir sinensis Milne-Edwards, 1853 and the European green crab Carcinus maenas (Linnaeus, 1758), both listed in the Global Invasive Species Database and among the 100 worst invasive species (Lowe et al. 2000). Amidst their relatively well-established presence in Europe and North America, invasive crabs are also known for their often devastating effects on the invaded environment and native biota (Holdich et al. 1999). Other invasive aquatic crustaceans, such as amphipods for example, have also created large concerns (Cuthbert et al. 2020b). A noteworthy example is the 'killer shrimp' Dikerogammarus villosus (Sowinsky, 1894) (e.g. Dick et al. 2002; Taylor and Dunn, 2017). 
Despite the recent advances in invasion science confirming the ecological notoriety of ICS as well as other aquatic crustaceans, economic analyses lag behind, and are partly overshadowed by the benefits brought by aquaculture and fishing industries. Direct and indirect costs associated with damages or losses from these taxa therefore remain scarce, resulting in minimal investments into research and management measures. To address this lack of information and highlight existing knowledge gaps in costs of their invasions worldwide, we utilized the InvaCost database, the most recent, comprehensive database of globally reported economic costs of IAS (Diagne et al. 2020a). This database contains detailed information on the costs (e.g. cost types, impacted sectors, regional attributes, cost estimation reliability, etc.) associated with $\sim 500$ invasive species. In the present study, we use a relevant subset of this database to describe the global costs associated with ICS and other aquatic invasive crustaceans to infer comparisons and understand the magnitude of their impacts. Moreover, we investigate how these costs are structured across space, time, cost types and sectors affected, as well as identify knowledge gaps in cost estimates.

\section{Methods}

\section{Data collection and filtering}

For the purpose of analyzing global costs of invasive aquatic crayfish, we used data from the InvaCost database (Diagne et al. 2020a), which primarily presents costs from English-written sources. InvaCost is a dynamic database that allows for corrections and additions of new cost entries as they develop or are reported throughout time. The first version of InvaCost comprised 2,419 reported economic costs of IAS retrieved from published peer-reviewed and grey literature (InvaCost v1; as of December 2019). More recently, those data have been supplemented with a search for costs recorded in fifteen of the most widely spoken languages, either as a mother tongue or second language $(5,212$ cost entries; Angulo et al. 2020), as well as via additional searches (2,374 entries; Ballesteros-Mejia et al. 2020). As of the timing of the writing (November 2020), the latest version of InvaCost (version 3.0, Diagne et al. 2020b; openly available at https://doi.org/10.6084/m9.figshare.12668570) consisted of 9,823 cost entries from IAS globally, after resolving duplications, allowing for comprehensive analysis of IAS at different taxonomic, spatial and temporal levels.

In compiling these data, grey and peer-reviewed literature were retrieved from standardised searches in online repositories (Web of Science, Google Scholar and Google search engine). The standardized searches, described in more detail in Diagne et al. (2020a), were enriched by targeted searches aiming at opportunistic collections of material containing cost information on IAS; these searches were performed through national databases, web pages of national institutions, NGOs and other organizations, as well as through contacts with regional national experts (Angulo et al. 2020). The collected material was thoroughly examined to assess relevance, and then scrutinized for collating cost estimates associated with aquatic crustaceans. Every cost entry recorded was described by various descriptors (Supplementary Material 1). 
We identified cost entries attributed to invasive freshwater crayfish, based on the "Order" classification by filtering out species belonging to "Decapoda" and thereafter entries belonging to relevant crayfish families ("Astacidae", "Cambaridae", "Parastacidae", and "Cambaroididae"). This resulted in a total of 112 entries. Additionally, to put the costs of invasive crayfish into perspective relative to other invasive crustaceans, we compared them to those of invasive amphipods (Order: Amphipoda; $n=1$ species), crabs (Infraorder: Brachyura and Anomura; $n=6$ ), and lobsters (Family: Nephropidae; $n=1$ ), on the basis of reported costs in the InvaCost database. Costs for these groups were extracted using (a) the "Order" column and selecting "Amphipoda", and (b) the "Family" column and selecting families of crabs and the family "Nephropidae", respectively. The identified cost entries for all crustaceans thus amounted to 120 entries attributed exclusively to aquatic species.

\section{Temporal cost dynamics, cost descriptors and comparisons across crustacean categories}

Deriving the total cumulative cost of invasions over time requires to consider the duration of each reported cost. The duration of each cost entry was inferred from the InvaCost database (columns "Probable starting year adjusted" and "Probable ending year adjusted"; see more details in Diagne et al. 2020b; http://borisleroy.com/invacost/Readme.html). When information was missing for the year that the costs started occurring, we conservatively considered the publication year of the original reference as the starting years for costs. In those cases where the last year over which costs occurred was missing, but the cost was listed as 'highly reliable' and 'potentially ongoing', costs were assumed to continue until 2020 (see Method reliability below). Costs in InvaCost were standardized to 2017 equivalent US\$ using the World Bank's market exchange rate and accounting for inflation through the Consumer Price Index of the year the cost was estimated for in each study. Using the duration time (in years) and the standardized costs in 2017 values (US\$), we annualised the data, with each entry corresponding to a given year. This step made cost entries of different types and durations comparable. For example, a total cost of $\$ 1,000$ between the years 2000 and 2009 would correspond to $\$ 100$ per year (see https://doi.org/10.6084/m9.figshare. 12668570 for further information). This process allowed us to analyze in a systematic manner the total cumulative cost along the defined period, resulting in 277 cost entries for invasive crayfish species, and considerably less for invasive crab species $(n=71)$, amphipods $(n=6)$, and lobsters $(n=2)$. We provided our final dataset used as a supplement (Supplementary Material 2).

Finally, the invasion costs were analysed based on the following five descriptors (described in more details in Diagne et al. 2020a; see Supplementary Material 1 and Diagne et al. 2020b):

(i) Method reliability: illustrating the perceived reliability of cost estimates based on the type of publication and method of estimation ("High" if costs were described in pre-assessed material (peerreviewed articles and official reports) or in grey material but with documented, repeatable and traceable methods; and "Low" otherwise); (ii) Implementation: referring to whether the cost estimate was actually realised in the invaded habitat ("Observed") or whether it was extrapolated based on expectations on costs beyond the invaded habitat and/or predicted over time ("Potential"); (iii) Geographic region: 
describing the continental geographic origin of the listed cost; costs that were not attributable to specific regions were categorised as "Diverse/Unspecified"; (iv) Type of cost merged: grouping of costs according to the categories: (a) "Damage-Loss", referring to damages or losses incurred by invasion (i.e. costs for damage repair, resource losses), (b) "Management costs", comprising expenditure such as monitoring, prevention, control, eradication and (c) "Mixed" costs, including a mix of categories (a) and (b) which include cases where reported costs were not easily distinguished between damage and control costs; and (v) Impacted sector: the activity, societal or market sector that was impacted by the cost. Individual cost entries not allocated to a single sector were classified under "Mixed" in the "Impacted sector" column.

For the purposes of analysing the economic costs of invasive crayfish and describing trends through time, we used the calculateRawAvgCosts function implemented in the R package "invacost" (Leroy et al. in prep; borisleroy.com/invacost/Readme.html). Using this method, we calculated the observed cumulative and average annual costs between the first recorded costs (2000) and last reported costs (2020), considering 5-year intervals.

Last we compared the costs of crayfish invasions to costs of other prominent crustacean invaders (crabs, amphipods, and lobsters) which has helped identify knowledge gaps and biases. Specifically, we focused on comparing how the total costs of these groups varied across species, impacted geographic regions, sectors of the economy, and the type of costs.

\section{Results}

\section{Economic costs across taxonomic groups}

The total costs of the 277 freshwater crayfish entries amounted to US\$ 1.28 billion, for the period 20002020. From this total cost, $94.5 \%$ was inferred from Astacidae (US\$ 1.21 billion; $n=159$ database entries) and $5.3 \%$ from Cambaridae (US\$ 67.8 million; $n=110$ ). Further, eight cost entries were classified as diverse or unspecified. No entries were reported for Parastacidae (crayfish native to the Southern Hemisphere) and Cambaroididae (endangered endemic species from Far-East Asia).

At the genus-level, US\$ 1.21 billion was attributed to the genus Pacifastacus (specifically the signal crayfish P. leniusculus (Dana, 1852); $=147$ ), US\$ 54.80 million were attributed to the genus Faxonius (34 entries with reported representative species previously attributed to Orconectes, see Crandall \& De Grave 2017); the rusty crayfish F. rusticus (Girard, 1852), the spiny-cheek crayfish F. limosus (Rafinesque, 1817), followed by US\$13.01 million to the genus Procambarus (the red swamp crayfish P. clarkii (Girard, $1852) ; n=76)$. Diverse or unspecific costs amounted to US 6.76 million $(n=20)$.

\section{Economic costs based on method reliability and implementation types}

Highly reliable cost entries comprised $99.8 \%$ of the documented total cost for freshwater crayfish (as well as 275 of 277 database entries, Fig. 1). Although most entries and cost estimates were classified as 'High' reliability, the vast majority of them were 'Potential' (US\$ 1.14 billion; 89.1\%) rather than 'Observed' 
(10.9\% of total costs, US\$ 141 million), implying that most were projected in time and/or space but have not necessarily been borne in practice. Note though that observed costs constituted the majority of database entries (207 out of 277 database entries, Fig. 1).

All invasive crayfish species with recorded costs in InvaCost were native to North America (Fig. 2). The majority of total ('Observed' and 'Potential') reported costs (US\$ 1.23 billion; $n=232$ ) were inferred in Europe, while US\$ 54.8 million (29 database entries) was related to certain parts of North America (specifically Wisconsin, which is north to the native range of rusty crayfish responsible for these costs) and relatively little in Asia (US\$ 292.73 thousand; $n=16$ ) (Fig. 3a). Accordingly, there was a striking absence of cost information for certain regions which include South America, Africa, and Oceania (Figs. 2 and 3).

In Europe, the vast majority of total costs were incurred in Sweden (US\$ 1.03 billion; $n=24$ ), followed by the United Kingdom (US\$ 176.75 million; $\mathrm{n}=91$ ); the costs in both countries were entirely due to $P$. leniusculus. Monetary impacts in Spain (US\$ 7.63 million; $n=69$ ), Portugal (US\$ 4.11 million; $n=2$ ) and France (US\$ 1.72 million; $n=37$ ) were significantly lower and mostly driven by $P$. clarkii, whereas those incurred in Italy (US\$ 6.29 million; $n=7$ ) were not linked to a specific species (Fig. 3a). Considering only observed costs, US\$116.41 million was attributed to Europe and US\$24.56 million to North America. Within Europe, 'Observed' costs were reported predominantly in the United Kingdom (US\$ 99.41 million; $n$ = 79), Spain (US\$ 7.63 million; $n=69$ ), Italy (US\$ 6.29 million; $n=7$ ), France (US\$ 1.72 million; $n=37$ ), Portugal (US\$ 1.22 million; $n=1$ ), and Norway (US\$ 145.36 thousand; $n=1$ ) (Fig. 3b).

\section{Economic costs among cost types and impacted sectors}

With respect to cost types, $83.2 \%$ of crayfish-related costs were attributed to damages or resource losses, and only $12.8 \%$ allocated to management expenditures on prevention, control or eradication; very few were classified as mixed (4.0\%). Regarding impacted sectors, the majority was, however, classified under "Mixed" sectors (US\$ 1.06 billion; 82.5\%; $n=35$ ), followed by impacts to "Authorities-Stakeholders" (US\$ 193.51 million; $15.1 \% ; n=204$ ), impacts to "Fishery" (US\$24.64 million; $1.9 \% ; n=20)$, and lastly to the categories "Environment" (US\$ 7.41 million; < 1\%; $n=17)$ and "Agriculture" (US\$ 1.22 million; < 1\%; $n=1$ ). Observed costs differed considerably, with $37.8 \%$ of costs (US\$ 53.6 million) being attributed to management expenditure, $25.8 \%$ (US\$ 36.4 million) to damage-losses, and $36.4 \%$ (US\$ 52.3 million) classified as mixed costs (Fig. 4a). The majority of observed costs were attributed to "AuthoritiesStakeholders" (US\$ 82.28 million; $58.4 \%$ ), substantially driven by P. leniusculus. This cost was followed by costs to "Fishery" (US\$24.64 million; 17.5\%), inferred by F. rusticus, "Environment" (US\$ 7.41 million; $5.3 \%$ ) and lastly "Agriculture" (US\$ 1.22 million; $<1 \%$ ), both majorly induced by P. clarkii. Costs attributed to "Mixed" sectors totalled at (US\$ 25.72 million; 18\%) (Fig. 4b).

\section{Temporal dynamics of costs}

For invasive crayfish, the recorded total cost of US\$ 1.28 billion between 2000 and 2020 (Fig. 5a) amounted to an average annual cost over the entire period of US\$ 61.14 million and to US\$ 6.71 million 
when only observed costs were considered. Because the effects of time lags in cost reporting were not incorporated into the analyses, average cost estimates tended to reach a plateau phase in recent years (Fig. 5). Nonetheless, reported costs have increased in the last two decades by two orders of magnitude.

\section{Costs of other crustaceans}

The reported costs of invasive crabs summed up to US\$ 1.25 billion, being based on costs for only five species: the $C$. maenas (US\$ 1.19 billion; $n=22$ ), followed by the $E$. sinensis (US\$ 62.79 million; $n=46$ ), the red king crab Paralithodes camtschaticus (Tilesius, 1815) (US\$ 915.67 thousand; $n=1$ ), the blue crab Callinectes sapidus Rathbun, 1896 (US\$ 20.75 thousand; $n=1$ ), and lastly the flower crab Portunus pelagicus (Linnaeus, 1758) (US\$ < 1 thousand; $n=1$ ) (Supplementary material 3a). The majority of crab invasion costs (94.9\%) was inferred in North America, with the majority of those (97.4\%) reported in Canada and the remaining costs reported in the USA. Significantly fewer costs $(<1 \%)$ were reported in Europe (Germany, Norway, and Spain) and Africa (Tunisia) (Supplementary Material 3b). The costs affected primarily the "Fishery" sector (US\$ 1.16 billion; $n=21$ ), with $3 \%$ (US\$ 32.19 million; $n=4$ ) of the costs attributed to "Authorities-Stakeholders" and 5\% (US\$ 62.79 million; $n=46)$ classified as "Mixed" costs. Almost all reported total costs $(99.9 \%)$ were attributed to damage costs, with very few attributed to management (Fig. 6a). In the past 20 years and since the first recorded crab cost in InvaCost, annual costs remained on average at US\$ 53 million. Between 2000 and 2020, crab invasion costs averaged at US\$ 53.10 million per year.

Overall, six expanded costs were inferred to amphipods, specifically the killer shrimp $D$. villosus, summing up to US\$ 178.8 thousand $(n=6)$. These costs were classified as "Damages and losses", impacting "Authorities-Stakeholders" solely in Europe (Italy). Lastly, the two recorded costs inferred to marine lobsters (Nephropidae) summed up to US\$ 44.6 thousand. Similar to amphipod costs, costs inferred by Nephropidae predominantly impacted Authorities-stakeholders in Europe (UK), but were attributed to "Management costs" (Fig. 6b).

\section{Discussion}

The present study is the first systematic analysis of global economic costs of invasive crayfish species and other aquatic crustaceans. Analysis of several cost descriptors helped identify key trends and knowledge gaps across spatial, taxonomic and temporal scales. Most reported crayfish costs were obtained from peer-reviewed literature and thus deemed "highly reliable", however, the vast majority were based on predictions or extrapolations arising from relatively few studies. As a result, there was a substantial difference between realized and predicted/expected costs of ICS. We identified four key costly species, P. clarkii, F. rusticus, F. limosus and P. leniusculus, with the latter representing the highest costs, while other damaging ICS were absent from the database. The analysis also includes comparison of ICS costs with other invasive crustaceans, namely crabs, amphipods and lobsters. 
Documented costs of ICS were found to be dominated by European countries, with comparatively few costs reported in North America, and Asia (Japan), and no costs reported for all other geographic regions, despite the global extent of crayfish invasions (Lodge et al. 2012; Ribeiro 2020). The absence of reported costs for Africa is noteworthy, as continental Africa and associated island nations are recipients of nine crayfish species (Madzivanzira et al. 2020).

Several prominent ICS have long introduction-histories in Europe (Holdich et al. 2009; Kouba et al. 2014). Dedicated research in recent years has enabled inclusion of several crayfish in the list of invasive species of EU concern, the Union list (European Commission 2016). As such, efforts to estimate and report costs in Europe might reflect a proactive stance on behalf of the European Union (European Commission 2014) in trying to understand the costs of ICS and limit their spread. Reported costs for ICS in Europe indicate that Sweden has been affected significantly. On the other hand, information on costs of ICS from South America, Africa, Oceania and Asia (except a few costs in Japan) were entirely absent, but can be expected in the future given the ongoing spread of ICS and targeted research in these regions (Horwitz and Knott 1995; Nunes et al. 2017; Madzivanzira et al. 2020; Oficialdegui et al. 2020b; Haubrock et al. in review). For instance, considering the growing production trends of $P$. clarkii in China in the last few years (global leading production country of crayfish, exceeding one million tonnes per year recently according to FAO 2020a), it is obvious that such a production cannot be reached without side effects. Indeed, this has become recognised as a national food security issue in the country, given that larger areas of agricultural land are permanently flooded, leaving less space for other crops including rice (Ho 2020), but environmental consequences are also indisputable. The lack of reported costs from diverse regions in InvaCost may be attributed to a number of reasons, which may span from the comparably shorter introduction histories, limited attention to aquatic environments, anecdotal reporting, low research effort on this topic and limited available funding, or limited accessibility to relevant cost information. However, this geographical bias is not unique to costs from invaded aquatic environments or ICS (see Early et al. 2016; Cuthbert et al. in review).

\section{Taxonomic biases}

Whilst overall costs of ICS were found to be substantial, the underlying cost quantification presented covers only a small subset of species from a few regions. For instance, $P$. leniusculus accounted for the largest share of the total cost, however, these were inferred only from northern European countries where targeted Plan Actions were developed to prevent reduction of native noble crayfish Astacus astacus (Linnaeus, 1758) stocks (Bohman and Edsman 2011). The second most costly crayfish invader in Europe, P. clarkii, was reported primarily in southern parts of the continent, where the majority of invaded habitats are found. These burgeoning costs of $P$. clarkii (US\$ 13.01 million) were estimated on the basis of 76 observations. The fact that this species is particularly widespread in Europe (Kouba et al. 2014), and already present in 40 countries of four continents with the potential for further spread (Oficialdegui et al. 2020b), highlights the knowledge gap in costs at a broader spatial but also temporal scale. Other highprofile ICS that are also listed by the EU as prominent invaders (European Commission 2016) but with no invasion costs reported, include $F$. virilis and the parthenogenetic marbled crayfish P. virginalis Lyko, 2017. 
The latter has a high spread potential (Hossain et al. 2018) and can be expected to cause considerable damage in the near future (Feria and Faulkes 2011). Additionally, cost data for some members of the Parastacidae family are lacking, despite their ubiquitous presence in substantial pathways such as aquaculture and pet trade (e.g. yabby $C$. destructor (Clark, 1936) and redclaw C. quadricarinatus (von Martens, 1868); Souty-Grosset et al. 2006; Madzivanzira et al. 2020; Haubrock et al. in review).

Given these knowledge gaps, the presented costs in our study are mostly driven by $P$. leniusculus, inferred from damage-losses and control actions. The vast majority of these costs were the result of extrapolations, possibly indicating a lack of empirical reporting effort and monitoring. This bias is noteworthy and worrisome, as applied management efforts are seemingly not dedicated to several highrisk species, e.g. P. clarkii (Gherardi et al. 2011; Souty-Grosset et al. 2016) or other emerging invasive ones (e.g. $C$. quadricarinatus and $P$. virginalis). For instance, dense burrowing has been signalled as especially problematic, affecting irrigation ditches and causing water leakages, but management is only scarcely conducted and is inherently challenging in cryptic aquatic ecosystems (Kouba et al. 2016; Haubrock et al. $2019 b)$. Further, ICS cause significant damages to hydraulic and irrigation systems, but information about the associated costs are largely missing (Tricarico et al. 2018; Madzivanzira et al. 2020). This could suggest a lack of management efforts on widely established ICS, and especially among Southern European countries. Note though that insufficient management could be attributed to the limited capacity to implement widespread management actions when ICS are so diffused (see management section below), and/or possibly a lack of adequate funding for such interventions.

The overall cost (categorized as damage-losses) impacted various sectors such as "Fisheries", "Environment" and "Public and social welfare". Only two recorded costs are reported for crayfish plague, specifically in Norway (US\$ 72.8 million: diverse/unspecified; US\$ 2 million). Costs associated with this pathogen are therefore heavily underestimated, as exemplified by numerous rapid population extinctions of native crayfish across Europe (Svoboda et al. 2017). Occurrence of chronically infected European native crayfish populations is a relatively rare and poorly understood phenomenon (Svoboda et al. 2017; Mojžišová et al 2020; Ungureanu et al. 2020). The pathogen is currently also known from further regions harbouring equally susceptible native crayfish in: South America (Peiró et al. 2016), Indonesia (Putra et al. 2018), and Japan (Martin-Torrijos et al. 2018; Mrugała et al. 2017), posing a threat to their remaining populations. Recent research efforts have focused on, the role of crabs (Schrimpf et al. 2014; Svoboda et al. 2014b; Tilmans et al. 2014) and shrimp (Mrugała et al. 2019; Putra et al. 2018; Svoboda et al. 2014a) as alternative hosts of this pathogen.

\section{Temporal biases}

Considering temporal trends, a complete lack of costs reported prior to 2000 indicates a large knowledge gap in how ICS have historically impacted human well-being and ecosystems. This is despite the long history of freshwater crayfish introductions worldwide and more than 150 years of crayfish plague outbreaks in Europe (Holdich et al. 2009; Kouba et al. 2014). In the case of P. clarkii, which is a costly and prominent invader especially in Southern Europe, most studies concerning its impact were not published 
until the end of 1990s, albeit being introduced in the 1970s (Oficialdegui et al. 2020b). This lag in bringing crayfish invasions to the attention of the scientific community and managers raises questions about ICS awareness, policies, perceptions and funding available for research prior to 2000. Given current invasion rates globally (Seebens et al. 2017) and future projections (Seebens et al. 2020), the high likelihood that known costs are broadly underestimated and poorly monetized along with trends over the past two decades, we expect that future research may shed more light on the true costs of ICS.

Data deficiencies in invaded regions as a whole can have knock-on effects, especially on cost reporting and estimation of potential costs. For example, the Upper Zambezi catchment has been invaded by $C$. quadricarinatus through multiple introductions since 2001 (Madzivanzira et al. 2020). There are known impacts of this invasion upon fisheries conferred through scavenging behaviours (Weyl et al. 2017; Madzivanzira et al. 2020) as well as consumptive effects on juvenile fish affecting recruitment (Madzivanzira et al. in review). The challenge can be attributed to poor or outdated assessments of the impacted fisheries which limits an understanding of their values and therefore the costs triggered by the invasion. This conundrum likely applies to other species and countries, such as P. clarkii in Kenya (Lowery and Mendes 1977), C. quadricarinatus in Mozambique (Chivambo et al. 2019), and $P$. virginalis in Madagascar (Andriantsoa et al. 2019). Indicatively, the $30 \%$ gill net catch reduction attributed to invasive crayfish in Zambian floodplains results in an estimated deficit of US\$128.33 per household which needs to be compensated for by increased fishing effort over time (Turpie et al. 1999). This cost, however, can be seen as a lower-bound estimate and highlights the challenges involved in valuing with confidence through time the damages caused by invasions. Even larger challenges apply to quantifying and valuing the loss in ecosystem services and the many forms of damage that occur indirectly (Pejchar and Mooney 2009; Spangenberg and Settele 2010; Schröter et al. 2014; Temel et al. 2018).

\section{Costs of other aquatic crustaceans}

Based on the reported costs of ICS, and considering that this taxonomic group remains largely understudied, it is not unreasonable to assume that costs for other related taxonomic groups such as invasive crabs or amphipods are also greatly underestimated. Having identified only five invasive crabs and one invasive amphipod species with reported costs (plus only two entries associated with invasive lobsters) indicates that there likely remain substantial knowledge gaps.

In comparison to other invasive crustaceans, ICS and invasive crabs dominated in terms of reported costs (being several magnitudes higher), although the number of reported costs was also several magnitudes higher in ICS than for invasive crabs. Indeed, costs of crabs were similar in magnitude, amidst originating from merely six unexpanded database entries (in contrast to the 114 unexpanded crayfish entries in InvaCost). This bias is noteworthy, because (a) commercial fisheries in marine environments are typically of much larger scale and commercial value compared to freshwater commercial fisheries and the same applies to commercial fisheries for marine vs. freshwater crustaceans (FAO 2020b) and (b) crab species recorded in InvaCost affect mainly the marine fishery sector. Invasion costs were not reported for many notorious and widespread invasive crabs, such as the $C$. maenas, Asian shore crab Hemigrapsus 
sanguineus (De Haan 1853) and the Harris mud crab Rhithropanopeus harrisii (Gould, 1841), which have marked economic and ecological impacts via predation on shellfish resources, spatially overlapping and causing costs to other commercial fisheries (Grosholz et al. 2000; Lohrer 2001; Zaitsev and Öztürk 2001; Boyle et al. 2010). Also, impacts of invasive crabs in poorly explored aquatic ecosystems such Arctic marine waters remain challenging due to limited understanding of baseline values and therefore costs of expanding crab invasions (Kourantidou et al. 2015; Kaiser and Kourantidou, in review). The snow crab Chionoecetes opilio (O. Fabricius, 1788) in the Barents Sea is one such prominent example which continues to grow at the cost of several benthic species (Kaiser et al. 2018). Commercial interest in harvesting this species may also hinder progress towards understanding their costs (Kourantidou and Kaiser 2019a). The red king crab Paralithodes camtschaticus is yet another example of high-impact invasion in Arctic waters which owing to its high commercial value is primarily managed as a commercial fishery rather than an invasion in Norway and exclusively as a commercial fishery in Russia, with ecosystem damages often downplayed (Kourantidou and Kaiser 2019b). Similarly, to other species, the present InvaCost database does not sufficiently cover the multiple costs associated to bycatches in spatially overlapping fisheries, predation and degradation upon native species (Skonhoft and Kourantidou, in review) or costs spent for baseline and restoration research (Kourantidou and Kaiser, in review). InvaCost is a living database that continues to be improved as reported costs become available.

Reposted costs of invasive amphipods were attributed exclusively to D. villosus. This notorious PontoCaspian invader has been shown to have marked impacts on a diverse range of prey types, including crayfish eggs/juveniles and fish eggs/larvae, with a greater feeding efficiency than native analogues towards vertebrates and invertebrates (Bollache et al. 2008; Taylor and Dunn 2017; Roje et al. 2021). Invasions by $D$. villosus can result in the extirpation of native species from freshwaters (Gergs and Rothhaupt 2015), and once established, populations can dominate native communities in terms of biomass and abundance (Josens et al. 2005; van Riel et al. 2006). Globally, only 27 alien species of gammarids have been reported, and these principally originate from the Ponto-Caspian region (Cuthbert et al. 2020b), with $96 \%$ of recognised gammarid invaders, thus lacking costs, as exemplified by the 'demon shrimp' $D$. haemobaphes (Eichwald 1841) having similar ecological effects as $D$. villosus (Constable and Birkby 2016).

\section{Invasion perception and management implications}

Despite their significance for socio-economic well-being and their susceptibility to change, aquatic invasions have overall received less attention (Maclsaac et al. 2011; Lynch et al. 2020; Cuthbert et al. in review). Often, both invaders and their impacts are challenging to monitor, which can lead to a series of knock-on effect time delays between impact reporting and management interventions (Beric and Maclsaac 2015), thus reducing the efficacy of preventative biosecurity measures (Coughlan et al. 2020), and hampering the understanding of their costs (Hanley and Roberts 2019). Crustaceans, however, have received comparatively substantial public attention, perhaps because of their prominent role in aquatic ecosystems or their popularity as food items (Kawai et al. 2015). The introduction of alien crustaceans, 
however, has not only induced a considerable native to alien species turnover (Kouba et al. 2014), but has also led to the loss of cultural heritages and traditions (Edsman 2004; Swahn 2004; Kataria 2007).

Public perceptions are of special consideration in the context of management responses (Höbart et al. 2020) and directly affect reporting of costs from invasions. Similar to other invasions, aquatic invasions may bring benefits (King et al. 2006; Christie et al. 2019), despite their harmful properties. Commercial and recreational fisheries for introduced crustaceans also contribute to a higher perceived value of these invasive species (Kourantidou and Kaiser 2019a). In low-income areas, they are often valued as a cheap source of protein or may contribute to regional economies (Andriantsoa et al. 2020; Haubrock et al. in review), resulting in limited recognition of costs (especially indirect ones) and possibly limited interest to understand impacts and identify related costs (Kourantidou and Kaiser 2019b). In Sweden, for example, the native crayfish $A$. astacus was largely extirpated by competition with the invasive $P$. leniusculus and transmission of the crayfish plague pathogen (Bohman and Edsman 2011), which itself has caused considerable monetary impact. As a result, the original source of income was largely replaced by $P$. leniusculus having a lower market price. The Swedish example, however, highlights how the almost complete loss of a native species (i.e. a considerable environmental and cultural damage-loss), along with costly spread control, created additional management costs. Similar substitutions towards the consumption of the introduced $P$. virginalis were also reported in Madagascar (Andriantsoa et al. 2019; 2020). Stakeholder interests at odds for certain species with perceived benefits may trigger conflicts in resource management (Zengeya et al. 2017; Oficialdegui et al. 2020a; Kourantidou and Kaiser 2019a; 2019b).

Reporting of invasion costs (foremost management and research related) relies on managers and stakeholders to have reached the end of a pathway which eventually leads to management interventions (Latombe et al. 2017). Pathways which lead up to applied management can vary but ultimately, they involve a risk assessment (e.g. Hawkins et al. 2015; Bacher et al. 2018), a classification of invasion status (e.g. Blackburn et al. 2011) and a choice of appropriate management intervention (see Robertson et al. 2020). However, formal risk assessments, specifically for crayfish species, are lacking (but see Roy et al. 2019; Yonvitner et al. 2020; Haubrock et al. in review). This could be due to either a data deficiency in evidence for crayfish impact assessments (such as in South Africa; Weyl et al. 2020) and/or due to the intensive nature of compiling contextually relevant impact assessments. Nevertheless, recent national horizon scanning exercises have ranked invasive crayfishes, crabs and amphipods as among the top ten risky species across all habitat types (Lucy et al. 2020).

Management intervention or cost reporting may be hindered in some cases due to public perceptions, stakeholder interests at odds and backlash, or lack of perceived necessity for management. Further, it is generally well-established in the literature that investment into control and management can lower damage-losses (Leung et al. 2002). In this study, total damages and resource losses were found to be an order of magnitude higher than control or management costs, suggesting the need for more proactive rather than reactive responses. However, management costs were dominant when considering empirically observed costs alone for ICS. Nonetheless, management attempts have largely failed at developing tools 
to hinder the spread or successfully eradicate widely established populations of invasive aquatic crustaceans (Gherardi et al. 2011; Stebbing et al. 2014; Haubrock et al. 2018). Indeed, feasible eradications are only possible under a narrow range of specific conditions (rather small, isolated localities) and with the use of drastic measures like long-term dewatering or application of non-selective biocides which may negatively affect the entire aquatic biota (Lidova et al. 2019; Manfrin et al. 2019; Peay et al. 2019; Chadwick et al. 2020). Therefore, effective management interventions may be impractical in many e.g. African or Asian systems because of their broad geographical expanse, besides their high costs. This is further underlined by the high cost and scale-specific methods used to control aquatic IAS in the USA or Europe (i.e. the use of rotenone, dewatering and draw-down methods). Furthermore, some management or control interventions may have unexpected adverse outcomes (Závorka et al. 2020; Loureiro et al. 2018). Developing effective means of introduction and spread prevention is therefore of key importance as crustacean invaders can lead to long-term persisting and growing invasion costs (Krieg and Zenker 2020).

\section{Conclusion}

In this study, we highlight that there is an exponentially increasing trend in reported costs of ICS since recording started in 2000. However, the currently available information is generally highly fragmented both spatially and taxonomically. Our analysis sheds light on several limitations and knowledge gaps in economic impacts of crayfish and other crustacean invasions. A better understanding of impacts, past and ongoing costs of ICS is therefore urgently needed to allow national and regional authorities to invest in appropriate policies and measures that can help mitigate those in the future. Considering the lack of reported costs across many invaded regions, despite well-known impacts of some ICS, the estimates provided in this study are probably very conservative. Nonetheless, despite being a rather small group taxonomically with only a few species having triggered invasions, the economic losses at a global level are substantial. Likewise, only five crab species represent significant invasion costs while amphipods are almost overlooked in this regard, indicating the dire need of investigating the true costs of invasive crustaceans. The costs identified along with the knowledge gaps highlighted in this study call for more effort to understand the impacts of invasive aquatic crustaceans on primary sectors as well as social and human wellbeing. A more thorough understanding of the positive values associated with crustacean invasions can help advance management and identify suitable compromises in those cases where stakeholder interests are conflicting.

\section{Eulogy}

This article is dedicated to Professor Olaf LF Weyl who passed away suddenly on November 14th, 2020. Prof. Olaf Weyl was a hugely influential scientist, mentor and dear friend, who described our African crayfish work as his 'pet project'. His giant presence, in every way, is sorely missed.

\section{Declarations}




\section{Funding}

The authors acknowledge the French National Research Agency (ANR-14-CE02-0021) and the BNPParibas Foundation Climate Initiative for funding the Invacost project that allowed the construction of the InvaCost database. The present work was conducted following a workshop funded by the AXA Research Fund Chair of Invasion Biology and is part of the AlienScenario project funded by BiodivERsA and Belmont-Forum call 2018 on biodiversity scenarios. AK acknowledges the Czech Science Foundation (project no. 19-04431S). FJO is funded by the Regional Government of Andalusia in Spain (Excelencia project P12-RNM 936). RNC acknowledges funding from the Alexander von Humboldt Foundation. JS acknowledges funding from the DSI-NRF Centre of Excellence for Invasion Biology (CIB).

\section{Data availability statement}

All the data used in this study was made available as supplementary material.

\section{Conflicts of interest/Competing interests}

No conflict of interest has to be declared.

\section{Availability of data and material}

The underlying data was provided as supplementary material.

\section{Code availability}

The R-code required has been referenced in the related sections within the methods.

\section{Authors' contributions}

AK, FJO, PJH, RNC and MK led the writing. PJH analysed data. JS, ET, BL, RG provided valuable insights and further literature. FC created the database. All authors contributed to all aspects of the manuscript production.

\section{References}

1. Ackefors HE (2000) Freshwater crayfish farming technology in the 1990s: a European and global perspective. Fish Fish 1(4):337-359. https://doi.org/10.1046/j.1467-2979.2000.00023.x

2. Andriantsoa R, Tönges S, Panteleit J et al (2019) Ecological plasticity and commercial impact of invasive marbled crayfish populations in Madagascar. BMC Ecol 19(8):1-10. https://doi.org/10.1186/s12898-019-0224-1

3. Andriantsoa R, Jones JP, Achimescu V et al (2020) Perceived socio-economic impacts of the marbled crayfish invasion in Madagascar. PloS ONE 15(4):e0231773. https://doi.org/10.1371/journal.pone.0231773 
4. Angulo E, Diagne C, Ballesteros-Mejia L et al (2020) Non-English database version of InvaCost. figshare. Dataset. https://doi.org/10.6084/m9.figshare.12928136.v2

5. Bacher S, Blackburn TM, Essl F et al (2018) Socio-economic impact classification of alien taxa (SEICAT). Methods Ecol Evol 9(1):159-168. https://doi.org/10.1111/2041-210X.12844

6. Ballesteros-Mejia L, Angulo E, Diagne C, Courchamp F, Invacost Consortia (2020) Complementary search database for Invacost. Figshare. Dataset. https://doi.org/10.6084/m9.figshare.12928145.v1

7. Beric B, Maclsaac HJ (2015) Determinants of rapid response success for alien invasive species in aquatic ecosystems. Biol Invasions 17(11):3327-3335. https://doi.org/10.1007/s10530-015-0959-3

8. Blackburn TM, Pyšek P, Bacher S et al (2011) A proposed unified framework for biological invasions. Trends Ecol Evol 26(7):333-339. https://doi.org/10.1016/j.tree.2011.03.023

9. Blackburn TM, Bellard C, Ricciardi A (2019) Alien versus native species as drivers of recent extinctions. Front Ecol Environ 17(4):203-207. https://doi.org/10.1002/fee.2020

10. Bohman P, Edsman $L$ (2011) Status, management and conservation of crayfish in Sweden: results and the way forward. Freshw Crayfish 18(1):19-26. http://doi.org/10.5869/fc.2011.v18.19

11. Bollache L, Dick JTA, Farnsworth KD, Montgomery WI (2008) Comparison of the functional responses of invasive and native amphipods. Biol lett 4(2):166-169.

https://doi.org/10.1098/rsbl.2007.0554

12. Boyle Jr T, Keith D, Pfau R (2010) Occurrence, reproduction, and population genetics of the estuarine mud crab, Rhithropanopeus harrisii (Gould)(Decapoda, Panopidae) in Texas freshwater reservoirs. Crustaceana, 83(4):493-505.

13. Bradley BA, Laginhas BB, Whitlock $R$ et al (2019) Disentangling the abundance-impact relationship for invasive species. Proc Natl Acad Sci U.S.A 116(20):9919-9924.

https://doi.org/10.1073/pnas.1818081116

14. Bradshaw CJ, Leroy B, Bellard C et al (2016) Massive yet grossly underestimated global costs of invasive insects. Nat Commun 7:12986. https://doi.org/10.1038/ncomms12986

15. Chadwick DD, Pritchard EG, Bradley P et al (2020) A novel 'triple drawdown' method highlights deficiencies in invasive alien crayfish survey and control techniques. J Appl Ecol (accepted). https://doi.org/10.1111/1365-2664.13758

16. Charles H, Dukes JS (2008) Impacts of invasive species on ecosystem services. In: Nentwig W (ed) Biological invasions. Springer, Berlin, pp 217-237

17. Chivambo S, Mussagy A, Barkic A (2019) Assessment of interspecific interactions between the invasive red-claw crayfish (Cherax quadricarinatus) and the Mozambique tilapia (Oreochromis mossambicus). Braz J Biol In press. https://doi.org/10.1590/1519-6984.217868

18. Christie H, Gundersen H, Rinde E et al. (2019) Can multitrophic interactions and ocean warming influence large-scale kelp recovery? Ecol Evol 9(5):2847-2862. https://doi.org/10.1002/ece3.4963

19. Collas M, Andrieu T (2019) Premier signalement de l'écrevisse à taches rouges (Faxonius rusticus, Girard 1852) en Europe, France (Département de l'Aveyron). (In French). http://especes-exotiques- 
envahissantes.fr/premier-signalement-de-lecrevisse-a-taches-rouges-faxonius-rusticus-girard-1852en-europe-france-departement-de-laveyron/ Accessed on 03 December 2020

20. Constable D, Birkby NJ (2016) The impact of the invasive amphipod Dikerogammarus haemobaphes on leaf litter processing in UK rivers. Aquat Ecol 50(2):273-281. https://doi.org/10.1007/s10452016-9574-3

21. Coughlan NE, Cuthbert RN, Dick JTA (2020) Aquatic biosecurity remains a damp squib. Biodivers Conserv 29:3091-3093. https://doi.org/10.1007/s10531-020-02011-8

22. Crandall KA, De Grave S (2017) An updated classification of the freshwater crayfishes (Decapoda: Astacidea) of the world, with a complete species list. J Crustac Biol 37(5):615-653. https://doi.org/10.1093/jcbiol/rux070

23. Crystal-Ornelas R, Hudgins E, Cuthbert RN et al. Economic costs of biological invasions within North America. Biol Invasions, this issue.

24. Cuthbert RN, Pattison Z, Taylor NG et al. Global economic costs of aquatic invasive alien species. Sci Total Environ (in review).

25. Cuthbert RN, Kotronaki SG, Dick JT, Briski E (2020) Salinity tolerance and geographical origin predict global alien amphipod invasions. Biol Lett 16(9):20200354. https://doi.org/10.1098/rsbl.2020.0354

26. Darwell W, Bremerich V, De Wever A et al (2018) The Alliance for Freshwater Life: A global call to unite efforts for freshwater biodiversity science and conservation. Aquatic Conserv 28(4):10151022. https://doi.org/10.1002/aqc.2958

27. Diagne C, Leroy B, Gozlan RE et al (2020a) InvaCost, a public database of the economic costs of biological invasions worldwide. Sci Data 7:277. https://doi.org/10.1038/s41597-020-00586-z

28. Diagne C, Leroy B, Gozlan RE et al (2020b) InvaCost: References and description of economic cost estimates associated with biological invasions worldwide. Figshare. Dataset. https://doi.org/10.6084/m9.figshare.12668570.v3

29. Dick JTA, Laverty C, Lennon JJ et al (2017) Invader Relative Impact Potential: a new metric to understand and predict the ecological impacts of existing, emerging and future invasive alien species. J Appl Ecol 54(4):1259-1267. https://doi.org/10.1111/1365-2664.12849

30. Dick JTA, Platvoet D, Kelly DW (2002) Predatory impact of the freshwater invader Dikerogammarus villosus (Crustacea: Amphipoda). Can J Fish Aquat Sci 59(6):1078-1084.

https://doi.org/10.1139/f02-074

31. Early R, Bradley BA, Dukes JS et al (2016) Global threats from invasive alien species in the twentyfirst century and national response capacities. Nat Commun 7:12485. https://doi.org/10.1038/ncomms12485

32. Edsman L (2004) The Swedish story about import of live crayfish. Bull Fr Pêche Piscic (372373):281-288. https://doi.org/10.1051/kmae:2004003

33. European Commission (2014) Regulation (EU) No 1143/2014 of the European Parliament and of the Council of 22 October 2014 on the prevention and management of the introduction and spread of invasive alien species. Off J Eur Union 57:35. 
34. European Commission (2016) Commission Implementing Regulation (EU) 2016/1141 of 13 July 2016 adopting a list of invasive alien species of Union concern pursuant to Regulation (EU) No $1143 / 2014$ of the European Parliament and of the Council. Official Journal of the European Union L 189, 14 July 2016, 4-8. http://data.europa.eu/eli/reg_impl/2016/1141/oj

35. FAO (2020) The State of World Fisheries and Aquaculture 2020. Sustainability in action. Rome. https://doi.org/10.4060/ca9229en

36. Faulkes Z (2015) The global trade in crayfish as pets. Crustac Res 44:75-92. https://doi.org/10.18353/crustacea.44.0_75

37. Faulkner KT, Robertson MP, Wilson JR (2020) Stronger regional biosecurity is essential to prevent hundreds of harmful biological invasions. Glob Chang Biol 26(4):2449-2462. https://doi.org/10.1111/gcb.15006

38. Feria TP, Faulkes Z (2011) Forecasting the distribution of Marmorkrebs, a parthenogenetic crayfish with high invasive potential, in Madagascar, Europe, and North America. Aquat Invasions 6(1):55-67. https://doi.org/10.3391/ai.2011.6.1.07

39. Frederico RG, Salvador GN, Andrade A, Rosa GR, Torquato GV (2019) Freshwater ecosystem vulnerability: Is native climatic niche good enough to predict invasion events? . Aquat Conserv Mar Freshw Ecosyst 29(11):1890-1896. https://doi.org/10.1002/aqc.3223

40. Gergs R, Rothhaupt K (2015) Invasive species as driving factors for the structure of benthic communities in Lake Constance, Germany. Hydrobiologia 746:245-254. https://doi.org/10.1007/s10750-014-1931-4

41. Gherardi F (2006) Crayfish invading Europe: the case study of Procambarus clarkii. Mar Freshw Behav Phy 39(3):175-191. https://doi.org/10.1080/10236240600869702

42. Gherardi F, Aquiloni L, Diéguez-Uribeondo J, Tricarico E (2011) Managing invasive crayfish: is there a hope? Aquat Sci 73(2):185-200. https://doi.org/10.1007/s00027-011-0181-z

43. Grosholz ED, Ruiz GM, Dean CA et al (2000) The impacts of a nonindigenous marine predator in a California bay. Ecology 81(5):1206-1224. https://doi.org/10.1890/00129658(2000)081[1206:TIOANM]2.0.CO;2

44. Hanley N, Roberts M (2019) The economic benefits of invasive species management. People Nat 1(2):124-137. https://doi.org/10.1002/pan3.31

45. Haubrock PJ, Johovic I, Balzani P et al (2018) The diet of the alien channel catfish Ictalurus punctatus in the River Arno (Central Italy). Aquat Invasions 13(4):575-585. https://doi.org/10.3391/ai.2018.13.4.14

46. Haubrock PJ, Balzani P, Criado A et al (2019a) Predicting the effects of reintroducing a native predator (European eel, Anguilla anguilla) into a freshwater community dominated by alien species using a multidisciplinary approach. Manag Biol Invasion 10(1):171-191. https://doi.org/10.3391/mbi.2019.10.1.11

47. Haubrock PJ, Inghilesi AF, Mazza G, Bendoni M, Solari L, Tricarico E (2019b) Burrowing activity of Procambarus clarkii on levees: analysing behaviour and burrow structure. Wetl Ecol Manag 
27(4):497-511. https://doi.org/10.1007/s11273-019-09674-3

48. Haubrock PJ, Oficialdegui FJ, Zeng Y et al. The redclaw crayfish: A prominent aquaculture species with invasive potential in tropical and subtropical biodiversity hotspots. Rev Aquacult (in review)

49. Haubrock PJ, Turbelin AJ, Cuthbert RN et al. Economic costs of invasive alien species across Europe. NeoBiota (in press)

50. Haubrock PJ, Bernery C, Cuthbert RN et al. Global economic impacts of invasive terrestrial invertebrates. Biol Invasions, this issue.

51. Haubrock PJ, Cuthbert RN, Ricciardi A, Diagne C, Courchamp F. Massive global economic costs of invasive macrofouling freshwater bivalves. Biol Invasions, this issue.

52. Hawkins CL, Bacher S, Essl F et al (2015) Framework and guidelines for implementing the proposed IUCN environmental impact classification for alien taxa (EICAT). Divers Distrib 21(11):1360-1363. https://doi.org/10.1111/ddi.12379

53. Höbart R, Schindler S, EssI F (2020) Perceptions of alien plants and animals and acceptance of control methods among different societal groups. NeoBiota 58:33-54.

https://doi.org/10.3897/neobiota.58.51522

54. Hoffmann BD, Broadhurst LM (2016) The economic cost of managing invasive species in Australia. NeoBiota 31:1-18. https://doi.org/10.3897/neobiota.31.6960

55. Holdich DM, Ackefors H, Gherardi F, Rogers WD, Skurdal J (1999) Native and alien crayfish in Europe: Some conclusions. In: Gherardi F, Holdich DM, editors. Crayfish in Europe as alien species. How to make the best of a bad situation? Rotterdam: A.A. Balkema, pp 281-292

56. Holdich DM, Reynolds JD, Souty-Grosset C, Sibley PJ (2009) A review of the ever increasing threat to European crayfish from non-indigenous crayfish species. Knowl Manag Aquat Ec (394-395):11. https://doi.org/10.1051/kmae/2009025

57. Horwitz P, Knott B (1995) The distribution and spread of the yabby Cherax destructor comples in Australia: speculations, hypotheses and the need for research. Freshw Crayfish 10(1):81-91.

58. Hossain MS, Patoka J, Kouba A, Buřič M (2018) Clonal crayfish as biological model: a review on marbled crayfish. Biologia 73(9):841-855. https://doi.org/10.2478/s11756-018-0098-2

59. Jackson MC (2015) Interactions among multiple invasive animals. Ecology 96(8):2035-2041. https://doi.org/10.1890/15-0171.1

60. Josens G, Bij de Vaate A, Usseglio-Polatera P et al (2005) Native and exotic Amphipoda and other Peracarida in the River Meuse: new assemblages emerge from a fast changing fauna. Hydrobiologia 542:203-220. https://doi.org/10.1007/s10750-004-8930-9

61. Kaiser BA, Kourantidou M, Fernandez LM (2018) A Case for the Commons: The Snow Crab in the Barents. J Environ Manage 210:338-348. https://doi.org/10.1016/j.jenvman.2018.01.007

62. Kaiser BA, Kourantidou M. Economic Considerations for Marine Invasions in a Warming Arctic. CABI Agriculture and Bioscience (in review) 
63. Kataria M (2007) A cost-benefit analysis of introducing a non-native species: The case of signal crayfish in Sweden. Mar Resour Econ 22(1):15-28. https://www.jstor.org/stable/42629533

64. Kawai T, Faulkes Z, Scholtz G (Eds.) (2015) Freshwater crayfish: a global overview. CRC Press, New York.

65. Kettunen M, Genovesi P, Gollasch S et al (2009) Technical support to EU strategy on invasive species (IAS): assessment of the impacts of IAS in Europe and the EU. (final module Rep. for Eur. Comm.), Serv. contract 070307/2007/483544/MAR/B2, Inst Eur Environ Policy (IEEP), Brussels.

66. King RB, Ray JM, Stanford KM (2006) Gorging on gobies: beneficial effects of alien prey on a threatened vertebrate. Can J Zool 84(1):108-115. https://doi.org/10.1139/z05-182

67. Kouba A, Petrusek A, Kozák, P (2014) Continental-wide distribution of crayfish species in Europe: update and maps. Knowl Manag Aquat Ec 413:5. https://doi.org/10.1051/kmae/2014007

68. Kouba A, Tíkal J, Císař P et al (2016) The significance of droughts for hyporheic dwellers: evidence from freshwater crayfish. Sci Rep 6:26569. https://doi.org/10.1038/srep26569

69. Kourantidou M, Kaiser BA, Fernandez LM (2015) Towards Arctic Resource Governance of Marine Invasive Species. In: Heininen L, Exner-Pirot H, Plouffe J (eds) Arctic Yearbook. Akureyri, Iceland: Northern Research Forum, pp 175-194

70. Kourantidou M, Kaiser BA (2019a) Sustainable seafood certifications are inadequate to challenges of ecosystem change. ICES J Mar Sci 76(4):794-802. https://doi.org/10.1093/icesjms/fsy198

71. Kourantidou M, Kaiser BA (2019b) Research agendas for profitable invasive species. J Environ Econ Policy 8(2):209-30. https://doi.org/10.1080/21606544.2018.1548980

72. Kourantidou M, Kaiser BA. Allocation of Research Resources for Commercially Valuable Invasions: Norway's Red King Crab Fishery Fisheries Research. (in review).

73. Krieg R, Zenker A (2020) A review of the use of physical barriers to stop the spread of non-indigenous crayfish species. Rev Fish Biol Fisher 30(3):423-435. https://doi.org/10.1007/s11160-020-09606-y

74. Latombe G, Pyšek P, Jeschke JM et al (2017) A vision for global monitoring of biological invasions. Biol Conserv 213:295-308. https://doi.org/10.1016/j.biocon.2016.06.013

75. Leroy B (2020) INVACOST, package for the R software. INVACOST Database With Methods To Analyse Invasion Costs. Current version: 0.1-3 (beta)

76. Leung B, Lodge DM, Finnoff D et al (2002) An ounce of prevention or a pound of cure: bioeconomic risk analysis of invasive species. Proc R Soc B 269(1508):2407-2413. https://doi.org/10.1098/rspb.2002.2179

77. Lidova J, Buřič M, Kouba A, Velisek J (2019) Acute toxicity of two pyrethroid insecticides for five nonindigenous crayfish species in Europe. Vet Med-Czech 64(3):125-133. https://doi.org/10.17221/136/2018-VETMED

78. Lipták B, Veselý L, Ercoli $F$ et al (2019) Trophic role of marbled crayfish in a lentic freshwater ecosystem. Aquat Invasions 14(2):299-309. https://doi.org/10.3391/ai.2019.14.2.09 
79. Liu C, Diagne C, Angulo E et al. Economic costs of biological invasions in Asia. Biol Invasions, this issue.

80. Lodge DM, Taylor CA, Holdich DM, Skurdal J (2000) Nonindigenous crayfishes threaten North American freshwater biodiversity: Lessons from Europe. Fisheries 25:7-20. https://doi.org/10.1577/1548-8446(2000)025<0007:NCTNAF>2.0.C0;2

81. Lodge DM, Deines A, Gherardi F et al (2012) Global introductions of crayfishes: evaluating the impact of species invasions on ecosystem services. Annu Rev Ecol Evol S 43:449-472. https://doi.org/10.1146/annurev-ecolsys-111511-103919

82. Lohrer AM (2001) The invasion by Hemigrapsus sanguineus in eastern North America: a review. Aquatic Invaders: The Digest of the National Aquatic Nuisance Species Clearinghouse 12:1-11.

83. Loureiro TG, Anastácio PM, Bueno SL de S, Araujo PB (2018) Management of invasive populations of the freshwater crayfish Procambarus clarkii (Decapoda, Cambaridae): test of a population-control method and proposal of a standard monitoring approach. Environ Monit Assess 190:559. https://doi.org/10.1007/s10661-018-6942-6

84. Lowe S, Browne M, Boudjelas S, De Poorter M (2000) 100 of the world's worst invasive alien species: a selection from the global invasive species database (Vol. 12). Invasive Species Specialist Group. Auckland, New Zealand

85. Lowery RS, Mendes AJ (1977) Procambarus clarkii in Lake Naivasha, Kenya, and its effects on established and potential fisheries. Aquaculture 11(2):111-121. https://doi.org/10.1016/00448486(77)90069-2

86. Lucy FE, Davis E, Anderson R et al (2020) Horizon scan of invasive alien species for the island of Ireland. Manag Biol Invasion 11(2):155-177. https://doi.org/10.3391/mbi.2020.11.2.01

87. Lynch AJ, Elliott V, Phang SC et al (2020) Inland fish and fisheries integral to achieving the Sustainable Development Goals. Nat Sustain 3:579-587. https://doi.org/10.1038/s41893-020-05176

88. Maclsaac HJ, Tedla RA, Ricciardi A (2011) Patterns and rate of growth of studies in invasion ecology. In: Richardson DM (ed) 50 years of invasion ecology: the legacy of Charles Elton. Wiley Blackwell, Chichester.

89. Madzivanzira TC, South J, Wood LE, Nunes AL, Weyl OLF (2020) A Review of freshwater crayfish introductions in Africa. Rev Fish Sci Aquac. https://doi.org/10.1080/23308249.2020.1802405

90. Madzivanzira TC, South J, Weyl OLF. Invasive crayfish have a predatory advantage over a native African freshwater crab at higher but not lower temperatures. Freshw Biol (in review)

91. Manfrin C, Souty-Grosset C, Anastácio PM, Reynolds J, Giulianini PG (2019) Detection and control of invasive freshwater crayfish: From traditional to innovative methods. Diversity 11(1):5. https://doi.org/10.3390/d11010005

92. Martin-Torrijos L, Kawai T, Makkonen J et al (2018) Crayfish plague in Japan: A real threat to the endemic Cambaroides japonicus PloS ONE 13:e0195353. https://doi.org/10.1371/journal.pone.0195353 
93. Mojžišová M, Mrugała A, Kozubíková-Balcarová E et al. (2020). Crayfish plague in Czechia: Outbreaks from novel sources and testing for chronic infections. J Invertebr Pathol 173:107390. https://doi.org/10.1016/j.jip.2020.107390

94. Mrugała A, Buríč M, Petrusek A, Kouba A (2019) May atyid shrimps act as potential vectors of crayfish plague? NeoBiota 51:65. https://doi:10.3897/neobiota.51.37718

95. Mrugała A, Kawai T, Kozubíková-Balcarová E, Petrusek A (2017) Aphanomyces astaci presence in Japan: a threat to the endemic and endangered crayfish species Cambaroides japonicus? Aquat Conserv 27:103-114. https://doi:10.1002/aqc.2674

96. Nunes AL, Zengeya TA, Measey GJ, Weyl OLF (2017) Freshwater crayfish invasions in South Africa: past, present and potential future. Afr J Aquat Sci 42(4):309-323. https://doi.org/10.2989/16085914.2017.1405788

97. Oficialdegui FJ, Delibes-Mateos M, Green AJ et al (2020a) Rigid laws and invasive species management. Conserv Biol 34(4):1047-1050. https://doi.org/10.1111/cobi.13481

98. Oficialdegui FJ, Sánchez MI, Clavero M (2020b) One century away from home: how the red swamp crayfish took over the world. Rev Fish Biol Fisher 30(1):121-135. https://doi.org/10.1007/s11160020-09594-z

99. Peay S, Johnsen SI, Bean CW et al (2019) Biocide treatment of invasive signal crayfish: successes, failures and lessons learned. Diversity 11(3):29. https://doi.org/10.3390/d11030029

100. Peiró DF, Almerão MP, Delaunay C et al (2016) First detection of the crayfish plague pathogen Aphanomyces astaci in South America: a high potential risk to native crayfish Hydrobiologia 781:181-190. https://doi:10.1007/s10750-016-2841-4

101. Pejchar L, Mooney HA (2009) Invasive species, ecosystem services and human well-being. Trends Ecol Evol 24(9):497-504. https://doi.org/10.1016/j.tree.2009.03.016

102. Pimentel D, Lach L, Zuniga R, Morrison D (2000) Environmental and economic costs of nonindigenous species in the United States. BioScience 50(1):53-65. https://doi.org/10.1641/00063568(2000)050[0053:EAECON]2.3.CO;2

103. Pimentel D, Zuniga R, Morrison S (2005) Update on the environmental and economic costs associated with alien-invasive species in the United States. Ecol Econ 52(3):273-288. https://doi.org/10.1016/j.ecolecon.2004.10.002

104. Putra MD, Bláha M, Wardiatno Y et al. (2018) Procambarus clarkii (Girard, 1852) and crayfish plague as new threats for biodiversity in Indonesia. Aquat Conserv. 28:1434-1440 https://doi:10.1002/aqc.2970

105. Pyšek P, Hulme PE, Simberloff D et al (2020) Scientists' warning on invasive alien species. Biol Rev 95(6):1511-1534. https://doi.org/10.1111/brv.12627

106. Reid AJ, Carlson AK, Creed IF et al (2019) Emerging threats and persistent conservation challenges for freshwater biodiversity. Biol Rev 94(3):849-873. https://doi.org/10.1111/brv.12480

107. Reynolds J, Souty-Grosset C (2011) Management of freshwater biodiversity: crayfish as bioindicators. Cambridge, UK: Cambridge University Press. 
108. Ribeiro FB (Ed.) (2020) Crayfish: Evolution, Habitat and Conservation Strategies. New York: Nova Science Publishers.

109. Robertson PA, Mill A, Novoa A et al (2020) A proposed unified framework to describe the management of biological invasions. Biol Invasions 22(9):2633-2645. https://doi.org/10.1007/s10530-020-02298-2

110. Roje S, Švagrová K, Veselý L et al (2021) Pilferer, murderer of innocents or prey? The potential impact of killer shrimp (Dikerogammarus villosus) on crayfish. Aquat Sci 83:5. https://doi.org/10.1007/s00027-020-00762-8

111. Roy HE, Bacher S, Essl F et al (2019) Developing a list of invasive alien species likely to threaten biodiversity and ecosystems in the European Union. Glob Chang Biol 25(3):1032-1048. https://doi.org/10.1111/gcb.14527

112. Schröter M, Van der Zanden EH, van Oudenhoven APE et al (2014) Ecosystem services as a contested concept: a synthesis of critique and counter-arguments. Conserv Lett 7(6):514-523. https://doi.org/10.1111/conl.12091

113. Schrimpf A, Schmidt T, Schulz R (2014) Invasive Chinese mitten crab (Eriocheir sinensis) transmits crayfish plague pathogen (Aphanomyces astaci) Aquat Invas 9:203-209. https://doi:10.3391/ai.2014.9.2.09

114. Seebens H, Blackburn TM, Dyer EE et al (2017) No saturation in the accumulation of alien species worldwide. Nat Commun 8:14435. https://doi.org/10.1038/ncomms14435

115. Seebens H, Bacher S, Blackburn TM et al (2020) Projecting the continental accumulation of alien species through to 2050. Glob Change Biol (in press) https://doi.org/10.1111/gcb.15333

116. Skonhoft A, Kourantidou M. Managing a natural asset that is both a value and a nuisance: Competition vs. Cooperation for the Barents Sea Red King Crab. Mar Resour Econ (in review)

117. South J, Madzivanzira TC, Tshali N, Measey J, Weyl OLF (2020) In a pinch: mechanisms behind potential biotic resistance toward two invasive crayfish by native African freshwater crabs. Front Ecol Evol 8:72. https://doi.org/10.3389/fevo.2020.00072

118. South J, McCard M, Khosa D et al (2019) The effect of prey identity and substrate type on the functional response of a globally invasive crayfish. NeoBiota 52:9-24. https://doi.org/10.3897/neobiota.52.39245

119. Souty-Grosset C, Holdich D, Noel P, Reynolds JD, Haffner P (eds) (2006) Atlas of Crayfish in Europe. Muséum national d'Histoire naturelle, Paris, Patrimoines naturels, 64, $187 \mathrm{pp}$

120. Souty-Grosset C, Anastacio PM, Aquiloni L et al (2016). The red swamp crayfish Procambarus clarkii in Europe: impacts on aquatic ecosystems and human well-being. Limnologica 58:78-93. https://doi.org/10.1016/j.limno.2016.03.003

121. Spangenberg JH, Settele J (2010) Precisely incorrect? Monetising the value of ecosystem services. Ecol Complex 7(3):327-337. https:// doi.org/10.1016/j.ecocom.2010.04.007

122. Stebbing $P$, Longshaw $M$, Scott $A$ (2014) Review of methods for the management of non-indigenous crayfish, with particular reference to Great Britain. Ethol Ecol Evol 26(2-3):204-231. 
https://doi.org/10.1080/03949370.2014.908326

123. Strayer DL (2010) Alien species in fresh waters: ecological effects, interactions with other stressors, and prospects for the future. Freshw Biol 55(1):152-174. https://doi.org/10.1111/j.13652427.2009.02380.x

124. Svoboda J, Mrugała A, Kozubikova-Balcarova E et al (2014a) Resistance to the crayfish plague pathogen, Aphanomyces astaci, in two freshwater shrimps J Inverteb Pathol 121:97-104. https://doi:10.1016/j.jip.2014.07.004

125. Svoboda J, Mrugała A, Kozubíková-Balcarová E et al A. (2017) Hosts and transmission of the crayfish plague pathogen Aphanomyces astaci: a review. J Fish Dis 40(1):127-140. https://doi.org/10.1016/S0308-8146(99)00264-2

126. Svoboda J, Strand DA, Vrålstad T et al (2014b) The crayfish plague pathogen can infect freshwaterinhabiting crabs Freshw Biol 59:918-929. https://doi:10.1111/fwb.12315

127. Swahn JÖ (2004) The cultural history of crayfish. Bull Fr Pêche Piscic (372-373):243-251.

128. Taylor NG, Dunn AM (2017) Size matters: predation of fish eggs and larvae by native and invasive amphipods. Biol Invasions 19:89-107. https://doi.org/10.1007/s10530-016-1265-4

129. Temel J, Jones A, Jones N, Balint L (2018) Limits of monetization in protecting ecosystem services. Conserv Biol 32(5):1048-1062. https://doi.org/10.1111/cobi.13153

130. Tilmans M, Mrugała A, Svoboda J et al. (2014) Survey of the crayfish plague pathogen presence in the Netherlands reveals a new Aphanomyces astaci carrier. J Invertebr Pathol 120:74-79. https://doi:10.1016/j.jip.2014.06.002

131. Tricarico E, Inghilesi AF, Brundu G et al (2018) Le specie aliene invasive: Cosa e come comunicare al grande pubblico - Guida tecnica per operatori didattici di orti botanici, zoo, musei scientifici, acquari e aree protette. LIFE ASAP ISBN: 978-88-943544-0-9

132. Turpie J, Smith B, Emerton L, Barnes J (1999) Economic valuation of the Zambezi basin wetlands. IUCN-The World Conservation Union Regional Office for Southern Africa, Harare (version adapted by IUCN 2003). Accessed 30 November 2020. https://www.cbd.int/financial/values/zambiavaluebarotse.pdf

133. Twardochleb LA, Olden JD, Larson ER (2013) A global meta-analysis of the ecological impacts of nonnative crayfish. Freshw Sci 32(4):1367-1382. https://doi.org/10.1899/12-203.1

134. Ungureanu E, Mojžišová M, Tangerman M et al (2020) The spatial distribution of Aphanomyces astaci genotypes across Europe: Introducing the first data from Ukraine. Fresh Crayfish 25(1):77-87. https://doi.org/10.5869/fc.2020.v25-1.077

135. Veselý L, Ruokonen TJ, Weiperth A et al (2020) Trophic niches of three sympatric invasive crayfish of EU concern. Hydrobiologia (accepted). https://doi.org/10.1007/s10750-020-04479-5

136. van Riel MC, van der Velde G, Rajagopal S et al (2006) Trophic relationships in the Rhine food web during invasion and after establishment of the Ponto-Caspian invader Dikerogammarus villosus. Hydrobiologia 565:39-58. https://doi.org/10.1007/s10750-005-1904-8 
137. Weiperth A, Bláha M, Szajbert B et al (2020) Hungary: a European hotspot of non-native crayfish biodiversity. Knowl Manag Aquat Ec 421:43. https://doi.org/10.1051/kmae/2020035

138. Weyl OLF, Nunes AL, Ellender BR et al (2017) Why suggesting Australian redclaw crayfish Cherax quadricarinatus as biological control agents for snails is a bad idea. Afr J Aquat Sci 42(4):325-327. https://doi.org/10.2989/16085914.2017.1414685

139. Weyl OLF, Ellender BR, Wassermann RJ et al. (2020) Alien Freshwater Fauna in South Africa. In: van Wilgen B, Measey J, Richardson D, Wilson J, Zengeya T (eds) Biological Invasions in South Africa. Invading Nature - Springer Series in Invasion Ecology, 14. Springer, Cham. https://doi.org/10.1007/978-3-030-32394-3_6

140. Woodward G, Perkins DM, Brown LE (2010) Climate change and freshwater ecosystems: impacts across multiple levels of organization. Philos Trans R Soc Lond B Biol Sci 365(1549):2093-2106. https://doi.org/10.1098/rstb.2010.0055

141. Yonvitner Y, Patoka J, Yuliana E et al (2020) Enigmatic hotspot of crayfish diversity at risk: Invasive potential of non-indigenous crayfish if introduced to New Guinea. Aquat Conserv 30(2):219-224. https://doi.org/10.1002/aqc.3276

142. Zaitsev Y, Öztürk B (2001) Exotic species in the Aegean, Marmara, Black, Azov and Caspian Seas. Istanbul, Turkey: Turkish Marine Research Foundation, 265 pp

143. Závorka L, Lassus R, Britton JR, Cucherousset J (2020) Phenotypic responses of invasive species to removals affect ecosystem functioning and restoration. Glob Change Biol 26(10):5693-5704. https://doi.org/10.1111/gcb.15271

144. Zengeya T, Ivey P, Woodford DJ et al (2017) Managing conflict-generating invasive species in South Africa: Challenges and trade-offs. Bothalia 47(2):a2160. http://dx.doi.org/10.4102/abc.v47i2.2160

\section{Figures}




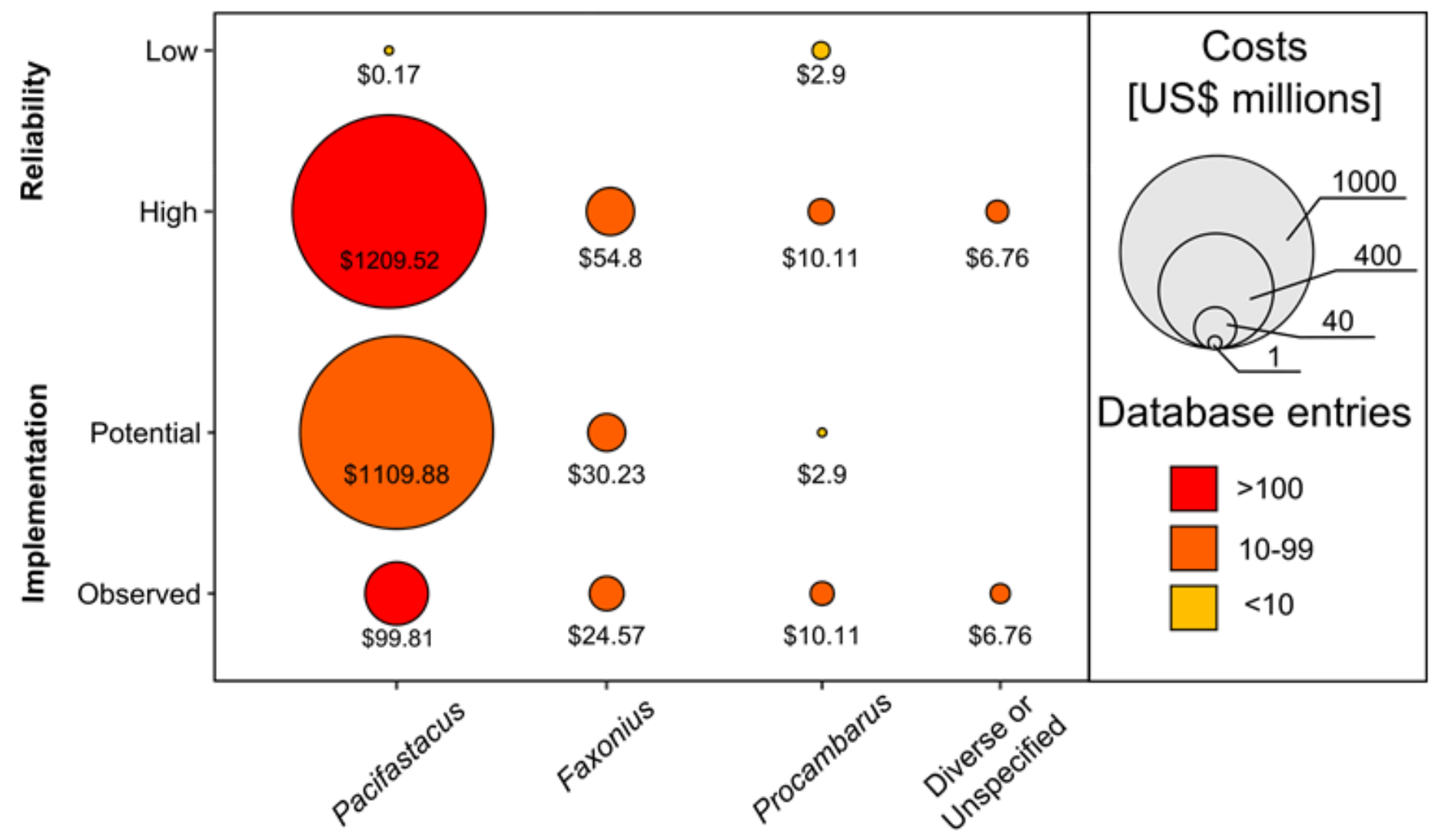

Figure 1

Global costs in US\$ millions (2017 value) of recorded invasive crayfish genera according to method reliability ('Low' vs. 'High') and implementation of cost ('Potential' vs. 'Observed'). Circle sizes depict the total amount of costs in US\$, whereas colouration indicates numbers of entries. 


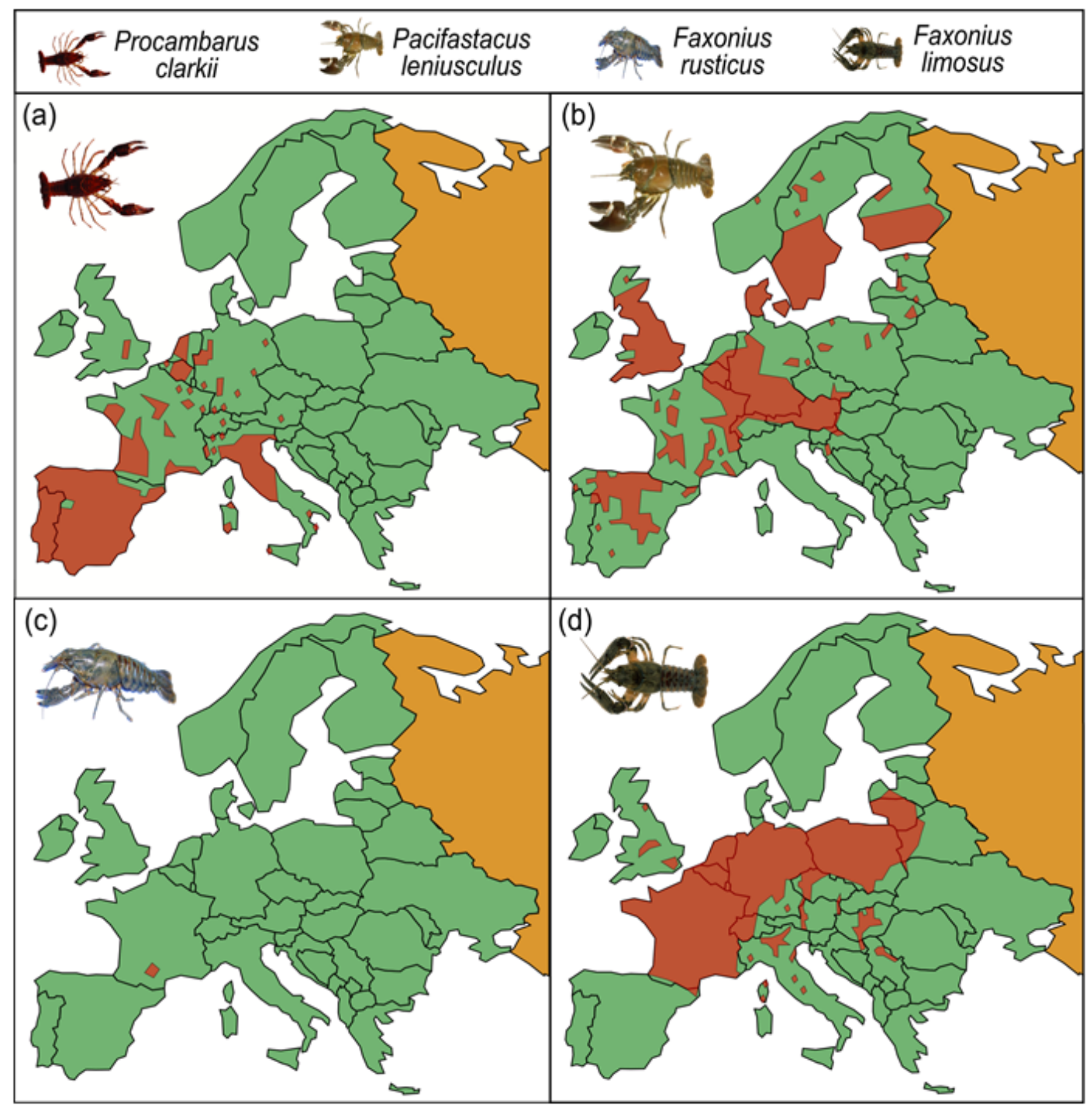

Figure 2

Indicative European distribution (red) of Procambarus clarkii (a), Pacifastacus leniusculus (b), Faxonius rusticus (c), and Faxonius limosus (d) (Kouba et al. 2014; Collas and Andrieu 2019). Note that reported costs of rusty crayfish are exclusively from North America. Note: The designations employed and the presentation of the material on this map do not imply the expression of any opinion whatsoever on the part of Research Square concerning the legal status of any country, territory, city or area or of its authorities, or concerning the delimitation of its frontiers or boundaries. This map has been provided by the authors. 


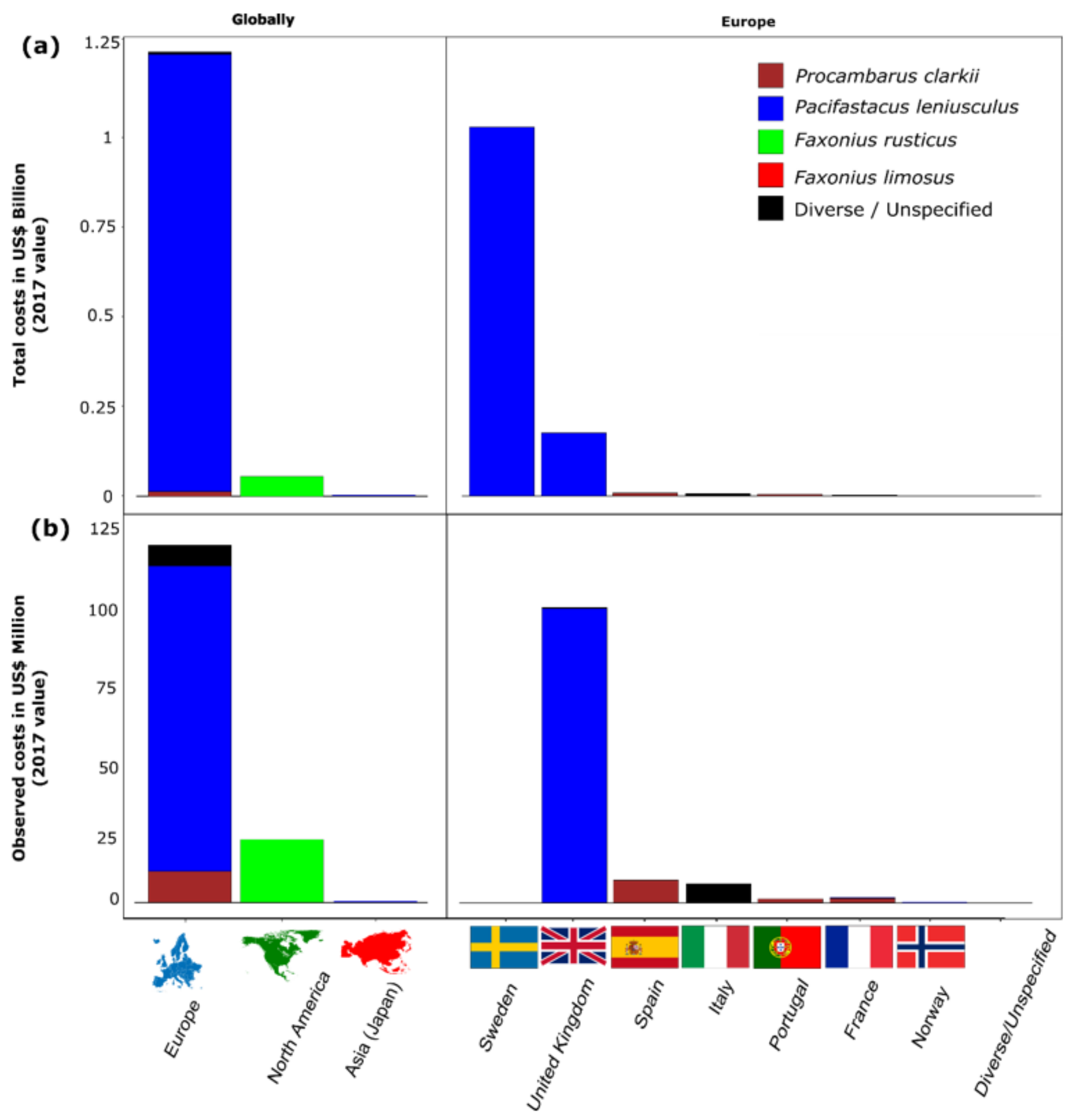

Figure 3

Distribution of total (a) and observed (b) invasive crayfish costs across continents and European countries. Note that subplot (a) is scaled in billions and (b) in millions. Note: The designations employed and the presentation of the material on this map do not imply the expression of any opinion whatsoever on the part of Research Square concerning the legal status of any country, territory, city or area or of its authorities, or concerning the delimitation of its frontiers or boundaries. This map has been provided by the authors. 


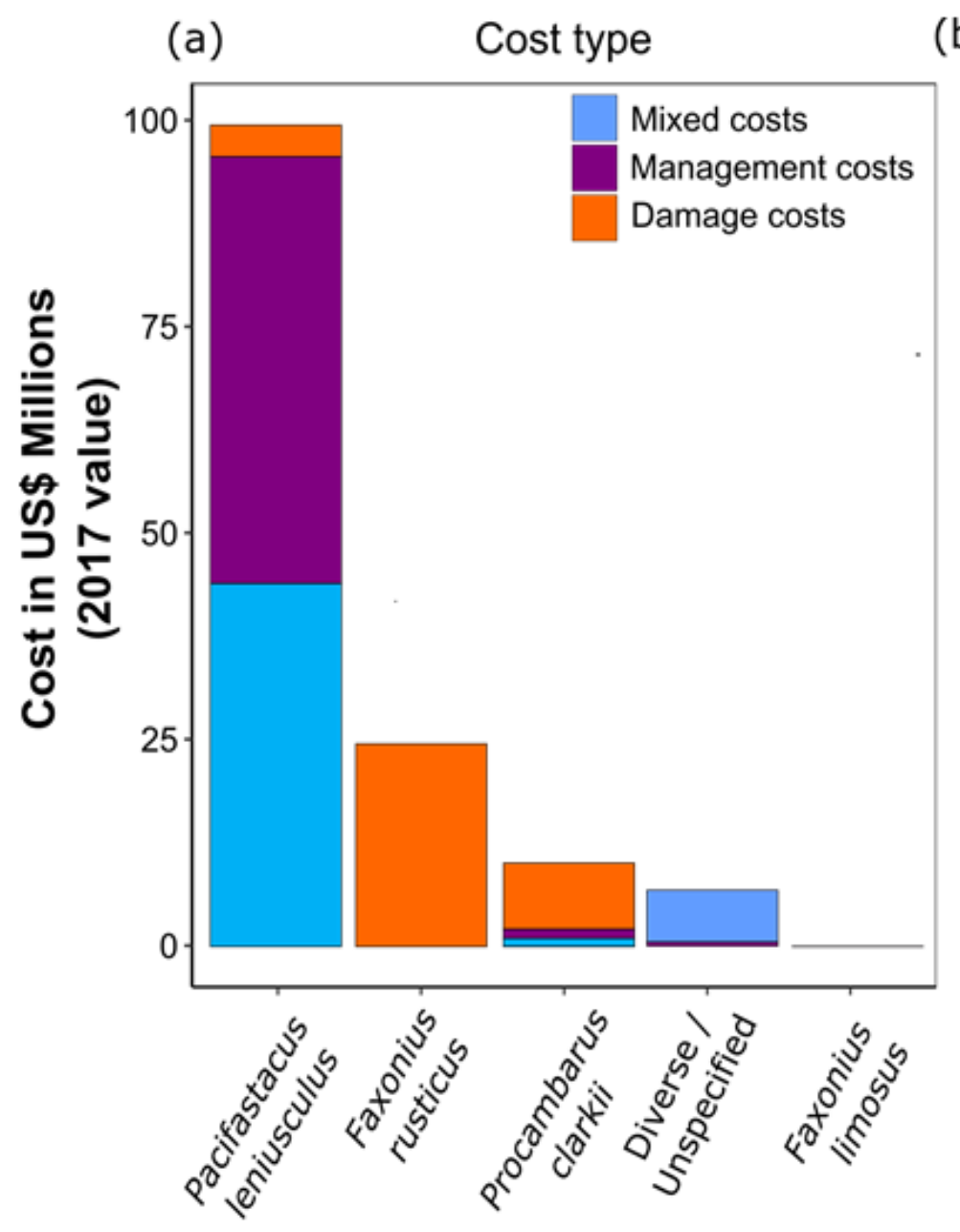

(b) Impacted sector

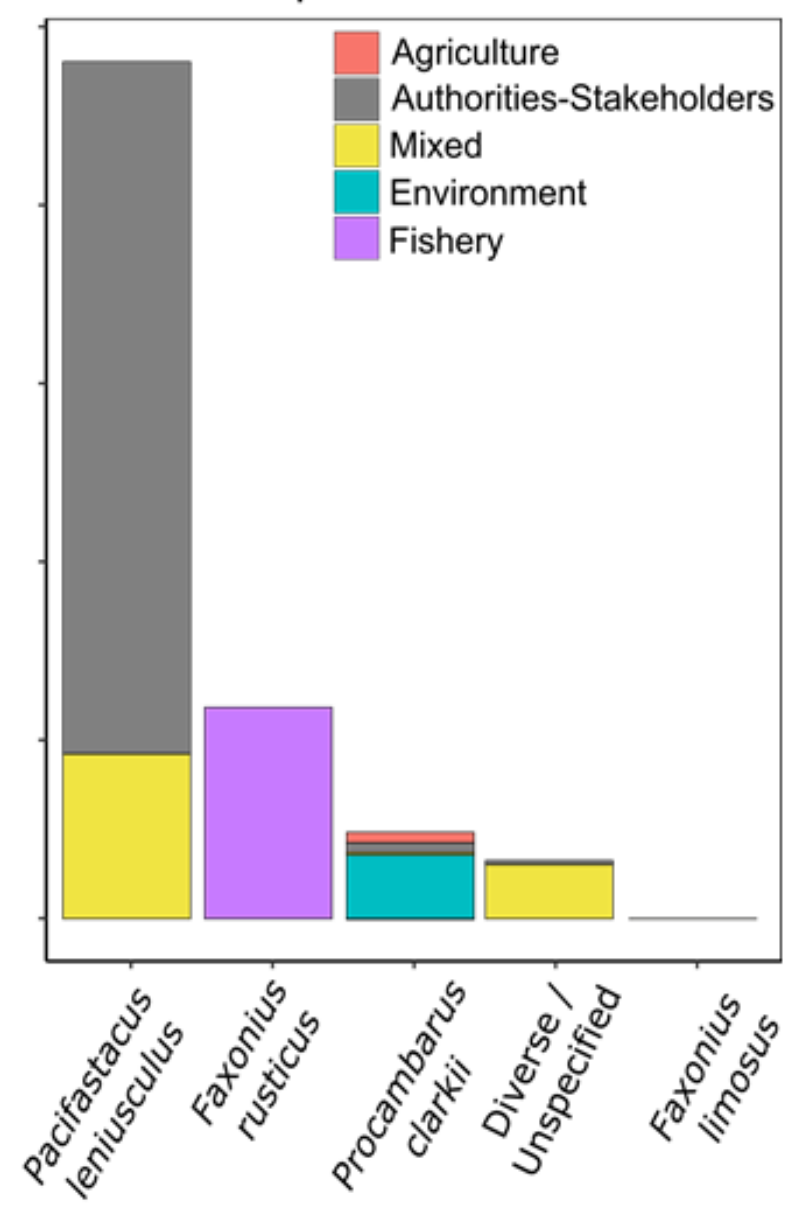

Figure 4

Observed economic cost estimates for invasive crayfish species according to cost type (a) and impacted sector (b). 

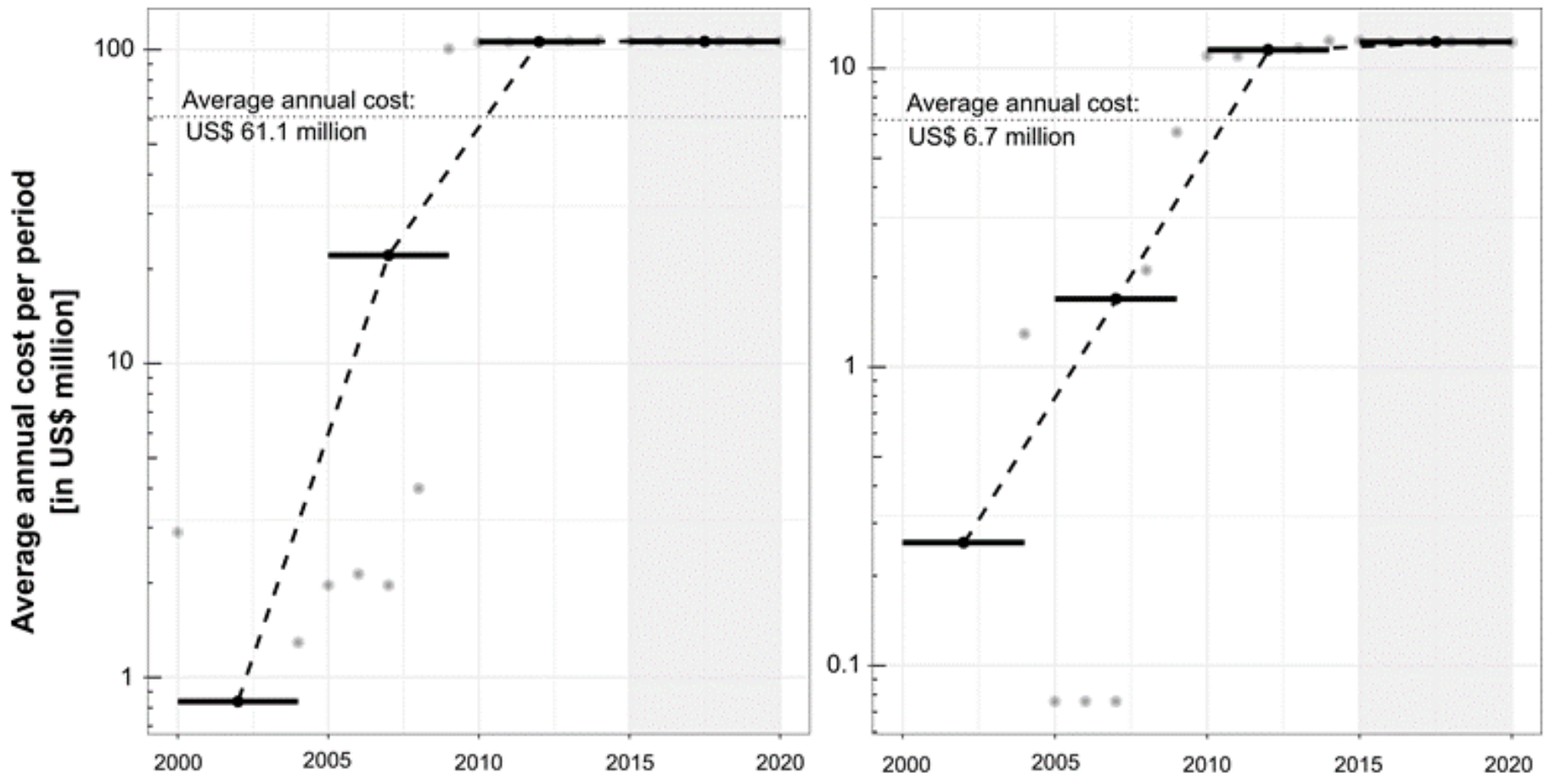

Figure 5

Temporal development of reported cumulative costs (total on the left vs. observed on the right) between $2000-2020$ of invasive crayfish. Points represent decadal means. Note that the last 5 years indicated in grey are subject to incompleteness in cost reporting and that the y-axes are shown on log10 scales that differ between subplots. 
(a)

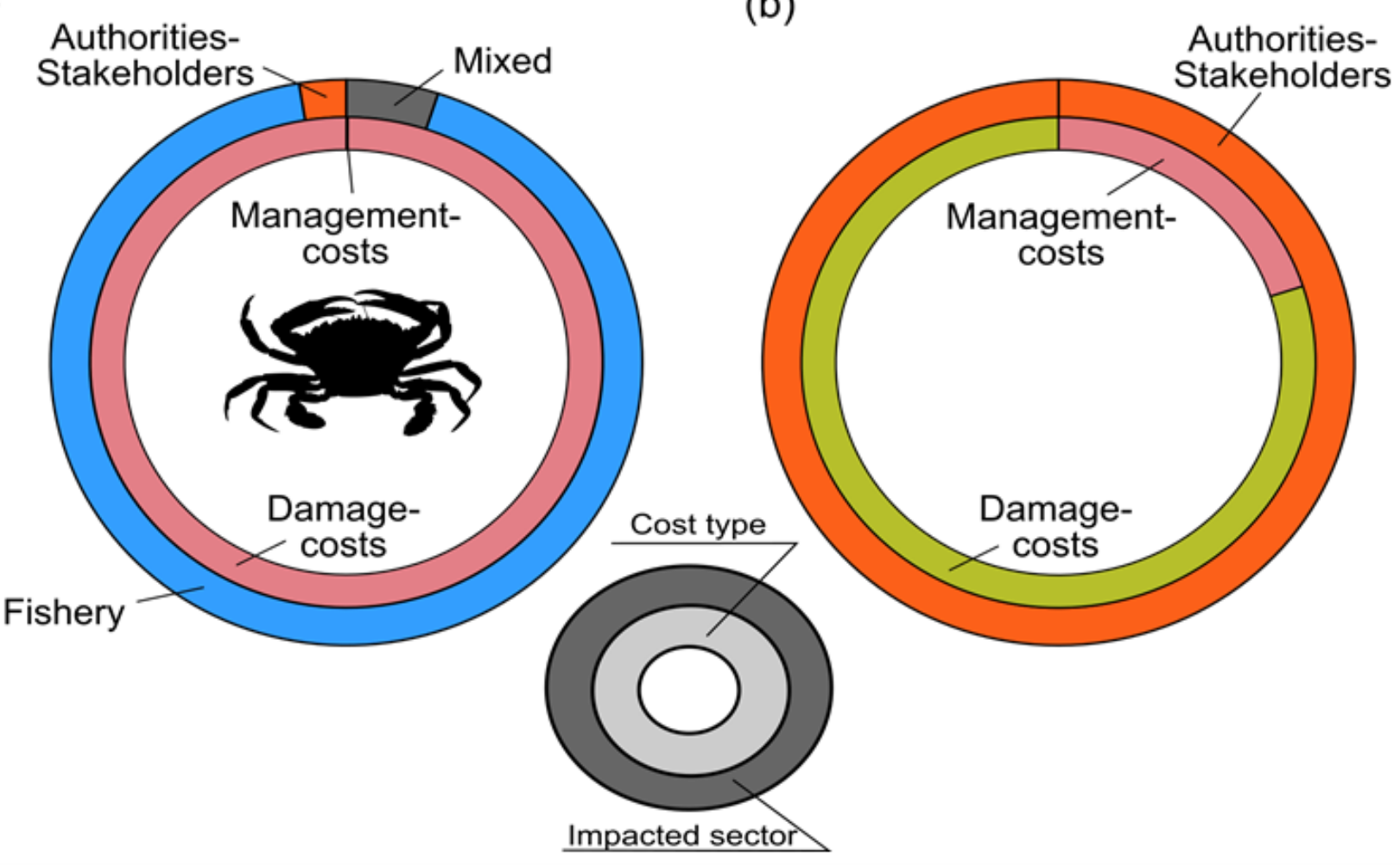

Figure 6

Share of (a) total crab costs vs. (b) total costs of amphipods and lobsters among sectors and cost types.

\section{Supplementary Files}

This is a list of supplementary files associated with this preprint. Click to download.

- S2.csv

- S3.docx

- S1.docx 